\title{
Cognitive impairment in patients with central nervous system
} tuberculosis

\section{Ignacio Popoca-Rodríguez and Graciela Cárdenas*}

Clinical Research Unit, Neuroinfectology Department, Instituto Nacional de Neurología y Neurocirugía "Manuel Velasco Suarez," Mexico City, Mexico

\begin{abstract}
Introduction: Tuberculosis (TB) in Mexico remains an important cause of morbidity and mortality; in the past 4 years, 110,681 cases of pulmonary tuberculosis and 1571 cases of tuberculous meningitis were reported. Objective: To determine the neurocognitive sequelae, clinical presentation and neuroimaging alterations in patients with central nervous system tuberculosis. Methods: A retrospective, analytical, and cross-sectional study was carried out from 2010 to 2019. Patients with central nervous system tuberculosis, with and without HIVIAIDS coinfection, were included. Results: During the study period, 104 cases with a definitive or probable central nervous system tuberculosis diagnosis were included; $38 \%$ had HIV/AIDS coinfection, and $55 \%$, various comorbidities ( $p=0.0001) ; 49 \%$ had cognitive alterations, and $14 \%$ died. Conclusions: Although HIV/AIDS infection can contribute to cognitive decline in patients with tuberculous meningitis, no differences were observed between patients with and without HIV/AIDS. Cognitive sequelae showed improvement during follow-up with adequate management and therapeutic control of the patients.
\end{abstract}

KEY WORDS: Cognitive impairment. Cognitive sequelae. Tuberculous meningitis. Central nervous system. HIV/AIDS.

\section{Deterioro cognoscitivo en pacientes con tuberculosis del sistema nervioso central}

\section{Resumen}

Introducción: La tuberculosis en México sigue siendo causa importante de morbimortalidad; en los últimos cuatro años, se reportaron 110681 casos de tuberculosis pulmonar y 1571 casos de tuberculosis meníngea. Objetivo: Determinar las secuelas neurocognoscitivas, presentación clínica y alteraciones en los estudios de neuroimagen en pacientes con tuberculosis del sistema nervioso central. Métodos: Se realizó un estudio retrospectivo, analítico y transversal de 2010 a 2019. Se incluyeron pacientes con tuberculosis del sistema nervioso central, con y sin coinfección por VIH/sida. Resultados: Durante el periodo de estudio se incluyeron 104 casos con diagnóstico definitivo y probable de tuberculosis del sistema nervioso central; de acuerdo con los criterios de Marais, $38 \%$ presentó coinfección por VIH/sida y $55 \%$, diversas comorbilidades ( $p=0.0001) ; 49 \%$ presentó alteraciones cognoscitivas y 14 \% falleció. Conclusiones: Aunque la infección por VIH/sida puede contribuir al deterioro cognitivo del paciente con tuberculosis meníngea, no se observaron diferencias entre pacientes con y sin VIH/sida. Las secuelas cognoscitivas mostraron mejoría en el seguimiento con el adecuado manejo y control terapéutico de los pacientes.

PALABRAS CLAVE: Deterioro cognitivo. Secuelas cognitivas. Tuberculosis meníngea. Sistema nervioso central. VIH/sida. 


\section{Introduction}

Today, tuberculosis (TB) is a major health problem worldwide owing to its high mortality. It is one of the ten leading causes of death and the first caused by a single infectious agent, whereby it surpasses HIV/AIDS infection. In this context, during 2018, 10 million people were estimated to be affected by TB in the world, which caused 1.2 million deaths in people without HIV infection and nearly 251,000 in people with HIV/AIDS. ${ }^{1}$ Central nervous system TB, particularly meningeal involvement, is the most serious and potentially fatal of all forms of extra-pulmonary involvement. ${ }^{2}$ In surviving patients, neurological sequelae are diverse, including motor and sensory disorders, hydrocephalus and cognitive impairment, ${ }^{3-5}$ which includes a gradual and progressive loss of mental functions in the domains of memory, orientation, abstraction, language, reasoning, executive functions, and learning and visuospatial skills. ${ }^{6,7}$ Although it is a multi-causal entity, systemic and central nervous system infections appear to play an important role, including HIV/AIDS infection. ${ }^{8,9}$

In Mexico, there is no information on neurological sequelae in patients with meningeal $\mathrm{TB},{ }^{10}$ particularly on cognitive impairment, which is why we decided to carry out a 9-year analytical, cross-sectional, retrospective study in patients admitted to a neurological referral center, with the purpose to evaluate mental functions compromise and cognitive impairment at hospital discharge (early involvement) and at 12 months of clinical follow-up (long-term); in addition, the possible risk factors of said population were evaluated.

\section{Methods}

A retrospective, analytical, cross-sectional study was carried out in adult patients cared for at the $\mathrm{Na}$ tional Institute of Neurology and Neurosurgery from 2010 to 2019. Marais et al. Meningeal TB Diagnostic Consensus criteria were used; ${ }^{11}$ only patients aged $\geq$ 15 years with a definitive diagnosis and those with probable diagnosis and clinical-radiological response to empirical treatment with antitubercular medications were included.

During hospitalization, patients were applied the Montreal Cognitive Assessment (MoCA) test and neuropsychological tests (NEUROPSI) in order to assess short-term memory, visuospatial skills, executive functions, attention, concentration and working memory, language and spatiotemporal orientation.

All qualitative variables were expressed as percentages, and their comparison was carried out using the chi-square test. Statistically significant differences were those with a $p$-value $<0.05$. Similarly, quantitative variables were expressed as means \pm standard deviations. Student's t-test or Mann-Whitney's U-test were used, depending on the behavior, for comparisons with Kolmogorov-Smirnov test. All data were analyzed with the SPSS program, version 22.

The research was approved by the Research Ethics Committee of the National Institute of Neurology with registration number 96/17.

\section{Results}

During the study period, 118 patients with clinical features suggestive of TB were detected, but only 104 met the inclusion criteria. These patients were cared for at the National Institute of Neurology and Neurosurgery.

\section{Population epidemiological characteristics}

Thirty-nine patients (38\%) with meningeal TB and HIV/AIDS coinfection and 65 (63\%) without HIV coinfection were included. Table 1 summarizes groups general characteristics. Patients in the group with HIV/ AIDS were significantly younger $(p=0.04)$. Median HIV viral load (at HIV infection diagnosis) was 1,111,944 (interquartile range $[I Q R]=476,822$ ), while median HIV viral load at TB diagnosis was 69,055 (IQR = 196,749). Regarding lymphocyte subpopulations, median CD4+ T lymphocytes (at HIV diagnosis) was 111/ $\mathrm{mm}^{3}(\mathrm{IQR}=198)$, whereas at TB diagnosis it was 126/ $\mathrm{mm}^{3}(\mathrm{IQR}=208)$.

According to Marais et al. criteria, ${ }^{11}$ in our population, a definitive diagnosis was observed in $30 \%$ and a probable diagnosis in the rest, although with clinical and radiological adequate response to anti-tubercular medications.

\section{Clinical characteristics}

In the overall population, the most common clinical presentation was meningitis $(62 \%, n=64)$ and hydrocephalus $(5 \%, n=5)$. Other manifestations (cognitive impairment, secondary vasculitis, etc.) were observed in $34 \%(n=35)$. There were no statistically significant 
Table 1. General characteristics of the groups

\begin{tabular}{|c|c|c|c|c|c|}
\hline \multirow[t]{2}{*}{ Characteristic } & \multicolumn{4}{|c|}{ Meningeal TB } & \multirow[t]{2}{*}{ p-value } \\
\hline & \multicolumn{2}{|c|}{ HIV/AIDS coinfection $(n=39)$} & \multicolumn{2}{|c|}{ No HIV coinfection $(n=65)$} & \\
\hline \multirow[t]{2}{*}{ Age in years, median (IQR) } & \multicolumn{2}{|c|}{$31(10)$} & \multicolumn{2}{|c|}{$40(27)$} & 0.04 \\
\hline & N & $\%$ & $n$ & $\%$ & \\
\hline $\begin{array}{l}\text { Gender } \\
\text { Males } \\
\text { Females }\end{array}$ & $\begin{array}{c}37 \\
2\end{array}$ & $\begin{array}{c}95 \\
5\end{array}$ & $\begin{array}{l}35 \\
30\end{array}$ & $\begin{array}{l}54 \\
46\end{array}$ & 0.0001 \\
\hline $\begin{array}{l}\text { Origin } \\
\text { Mexico City/metropolitan area } \\
\text { Other state }\end{array}$ & $\begin{array}{l}24 \\
15\end{array}$ & $\begin{array}{l}62 \\
38\end{array}$ & $\begin{array}{l}27 \\
38\end{array}$ & $\begin{array}{l}42 \\
58\end{array}$ & 0.06 \\
\hline History of pulmonary TB & 6 & 2 & 8 & 1 & 0.7 \\
\hline Comorbidities & 39 & 68 & 18 & 32 & 0.0001 \\
\hline $\begin{array}{l}\text { Clinical presentation } \\
\text { Meningitis } \\
\text { Hydrocephalus } \\
\text { Other }\end{array}$ & $\begin{array}{c}20 \\
2 \\
17\end{array}$ & $\begin{array}{c}51 \\
5 \\
44\end{array}$ & $\begin{array}{c}44 \\
3 \\
18\end{array}$ & $\begin{array}{c}68 \\
5 \\
28\end{array}$ & 0.09 \\
\hline $\begin{array}{l}\text { Clinical outcome } \\
\text { Survival } \\
\text { Death }\end{array}$ & $\begin{array}{c}32 \\
7\end{array}$ & $\begin{array}{l}82 \\
18\end{array}$ & $\begin{array}{c}57 \\
7\end{array}$ & $\begin{array}{l}89 \\
11\end{array}$ & 0.0001 \\
\hline
\end{tabular}

differences in clinical presentation between patients with and without HIV/AIDS coinfection. The state of consciousness, evaluated using the Glasgow coma scale, had an average score of $14 \pm 2.2$ at admission in the entire population, and at discharge, $13.3 \pm 4.4$.

\section{Neuroimaging features}

All patients underwent magnetic resonance imaging (MRI), with the main findings being meningitis or leptomeningeal enhancement $(n=31,24 \%)$, abscesses or collections ( $n=38,29 \%)$, ischemia/infarcts $(n=6$, $4.6 \%$ ) and hydrocephalus $(n=5,5 \%)$. Secondary vasculitis was reported in 33 patients (25\%) by transcranial Doppler ultrasound.

\section{Complementary studies}

In all cases, bacteriological cultures were processed in Lowestein-Jensen medium; however, isolation was only achieved in 21 patients (20\%), as determined in biological samples: cerebrospinal fluid in five cases $(23 \%)$, bronchial secretion in six $(29 \%)$ and urine in 10 (48\%). GeneXpert cerebrospinal fluid PCR test was positive in 15 patients (13\%). Cerebrospinal fluid cytochemical examination showed characteristics of inflammation, and cellularity was higher in the group with HIV coinfection $(p=0.03)$. No significant differences were identified between groups in terms of adenosine deaminase (ADA) levels at admission or during clinical follow-up (Table 2).

\section{Neurocognitive evaluation}

Neurocognitive alterations were found in our population, including significant short-, mid-, and long-term memory loss; as well as loss of thinking ability, judgment, and executive skills and verbal fluency alteration, and even mood alterations, with regard to which mild depression predominated according to evaluation with the MoCA and NEUROPSI tests. MoCA assessment was carried out at hospital admission and during outpatient follow-up before and after 12 months post-discharge. At hospital admission, mean score in patients with HIV/AIDS coinfection was $23.4 \pm 5.7$; on follow-up evaluation before 12 months, it was $24.3 \pm 4.4$ ( $p=$ $0.01)$, and after 12 months, it was $26.6 \pm 0.5(p=0.02)$; patients without HIV coinfection showed a score of 24.1 \pm 5.3 at admission, $23.7 \pm 5.6$ on follow-up before 12 months, and $24 \pm 7.1$ after 1-year follow-up.

Visuospatial alteration was observed in 16 patients (41\%) with HIV/AIDS coinfection, as well as identification 
Table 2. Complementary studies and CSF analysis characteristics

\begin{tabular}{|c|c|c|c|c|c|}
\hline \multirow[t]{3}{*}{ Characteristic } & \multicolumn{4}{|c|}{ Meningeal TB } & \multirow[t]{3}{*}{ p-value } \\
\hline & \multicolumn{2}{|c|}{ HIV/AIDS coinfection $(n=39)$} & \multicolumn{2}{|c|}{ No HIV coinfection $(n=65)$} & \\
\hline & Median & IQR & Median & IQR & \\
\hline $\begin{array}{l}\text { CSF cytochemistry at meningeal TB diagnosis } \\
\text { Glucose }(\mathrm{mg} / \mathrm{dL}) \\
\text { Protein }(\mathrm{mg} / \mathrm{dL}) \\
\text { Cells } / \mathrm{mm}^{3}\end{array}$ & $\begin{array}{l}44 \\
81 \\
37\end{array}$ & $\begin{array}{l}24 \\
159 \\
125\end{array}$ & $\begin{array}{c}45 \\
115 \\
96\end{array}$ & $\begin{array}{c}47 \\
1594 \\
298\end{array}$ & $\begin{array}{l}0.7 \\
0.4 \\
0.03\end{array}$ \\
\hline Admission ADA (IU/L) & 7 & 13 & 7 & 12 & 0.4 \\
\hline Follow-up ADA (IU/L) & 4 & 7 & 3 & 9 & 0.5 \\
\hline
\end{tabular}

alteration in six (15.4\%), language alteration in $12(30.8 \%)$, abstraction alteration in 12 (30.8\%), memory alteration in $20(51.3 \%)$ and orientation alteration in $13(33.3 \%)$. In the group without HIV coinfection, visuospatial alterations were observed in 23 patients $(37.7 \%)$, identification alteration in eight $(13.1 \%)$, language alteration in 17 (27.4\%), abstraction alteration in $16(25.8 \%)$, memory alteration in 30 (47.3\%) and orientation alteration in 16 (25.8\%). There were no statistically significant differences between groups (Table 3 ).

Attention was found to be more frequently altered in patients with HIV/AIDS coinfection (26 cases, $66.7 \%)$, which translated into statistically significant relevance $(p=0.02)$

There were no significant differences in the degree of impairment severity between groups; however, patients in whom manifestations started with neurocognitive deterioration alterations at hospital admission were more prone to develop subsequent permanent alterations $(p=0.001)$.

\section{Treatment}

All patients received DOTBAL (rifampicin, pyrazinamide, ethambutol and isoniazid), pyridoxine and dexamethasone $0.3 \mathrm{mg} /$ day for three weeks, with subsequent de-escalation with oral prednisone during hospitalization. Antitubercular treatment intensive phase consisted of 60 doses, while the maintenance phase lasted 15 to 18 months, according to neuroimaging findings.

Among 104 patients who received empirical treatment, $70 \%$ had a favorable response (clinical and radiological) to it.

Treatment effectiveness had no relevance in the presence of cognitive impairment $(p=0.4)$, deterioration severity degree $(p=0.2)$ or appearance of sequelae at discharge $(p=0.3)$.

\section{Discussion}

Meningeal TB continues to have a high mortality rate, and thus constitutes an alarming public health problem. ${ }^{12}$ In this research, very few patients had active pulmonary TB or a history thereof at diagnosis; at the same time, few patients had HIV as a risk factor, unlike what is documented in the literature. ${ }^{13}$ Clinical manifestations and findings on imaging studies were similar to those described in other investigations, predominantly data consistent with meningitis and collections..$^{14,15}$

No statistical relevance was recorded in clinical presentation, imaging findings or cerebrospinal fluid inflammatory characteristics in patients with or without HIV/AIDS coinfection.

Multiple studies in the literature have demonstrated that cognitive deterioration in people with HIV is closely related, most notably in people who are not yet on treatment. ${ }^{16}$ Efficacious antiretroviral treatment exponentially delays cognitive impairment. ${ }^{17}$

Cognitive impairment was slightly higher in patients with HIVIAIDS (51.3\%) than in patients without HIV coinfection (47.7\%); however, in patients with HIV/AIDS, moderate impairment (55\%) was predominant, and in patients without HIV, severe impairment (58.1\%). Cognitive sequelae occurred in both groups, with no differences.

Even when central nervous system TB in patients with HIV/AIDS is associated with a higher risk of cognitive impairment, no higher degree of severity or sequelae were demonstrated in these patients. During follow-up, improvement of previously defined sequelae was observed in both groups (with and without HIV infection), with higher scores in patients with HIV/AIDS. 
Table 3. Alterations, severity and cognitive sequels according to MoCA test

\begin{tabular}{|c|c|c|c|c|c|}
\hline \multirow[t]{3}{*}{ Variable } & \multicolumn{4}{|c|}{ Meningeal TB } & \multirow[t]{3}{*}{ p-value } \\
\hline & \multicolumn{2}{|c|}{ HIV/AIDS coinfection $(n=39)$} & \multicolumn{2}{|c|}{ No HIV coinfection $(n=65)$} & \\
\hline & \multicolumn{2}{|c|}{ Mean \pm SD } & \multicolumn{2}{|c|}{ Mean \pm SD } & \\
\hline \multirow[t]{2}{*}{$\begin{array}{l}\text { MoCA } \\
\text { Admission } \\
<12 \text {-month follow-up } \\
>12 \text {-month follow-up }\end{array}$} & \multicolumn{2}{|c|}{$\begin{array}{l}23.4 \pm 5.7 \\
24.3 \pm 4.4 \\
26.6 \pm 0.5\end{array}$} & \multicolumn{2}{|c|}{$\begin{array}{l}24.1 \pm 5.3 \\
23.7 \pm 5.6 \\
24 \pm \geq 7.1\end{array}$} & $\begin{array}{l}0.9 \\
0.01 \\
0.02\end{array}$ \\
\hline & $n$ & $\%$ & $\mathrm{n}$ & $\%$ & \\
\hline $\begin{array}{l}\text { Visuospatial alteration } \\
\text { Yes } \\
\text { No }\end{array}$ & $\begin{array}{l}16 \\
23\end{array}$ & $\begin{array}{c}1 \\
59\end{array}$ & $\begin{array}{l}23 \\
38\end{array}$ & $\begin{array}{l}37.7 \\
62.3\end{array}$ & 0.7 \\
\hline $\begin{array}{l}\text { Identification alteration } \\
\text { Yes } \\
\text { No }\end{array}$ & $\begin{array}{c}6 \\
33\end{array}$ & $\begin{array}{l}15.4 \\
84.6\end{array}$ & $\begin{array}{c}8 \\
53\end{array}$ & $\begin{array}{l}13.1 \\
86.9\end{array}$ & 0.7 \\
\hline $\begin{array}{l}\text { Attention alteration } \\
\text { Yes } \\
\text { No }\end{array}$ & $\begin{array}{l}26 \\
13\end{array}$ & $\begin{array}{l}66.7 \\
33.3\end{array}$ & $\begin{array}{l}27 \\
35\end{array}$ & $\begin{array}{l}43.5 \\
56.5\end{array}$ & 0.02 \\
\hline $\begin{array}{l}\text { Language alteration } \\
\text { Yes } \\
\text { No }\end{array}$ & $\begin{array}{l}12 \\
27\end{array}$ & $\begin{array}{l}30.8 \\
69.2\end{array}$ & $\begin{array}{l}17 \\
45\end{array}$ & $\begin{array}{l}27.4 \\
72.6\end{array}$ & 0.7 \\
\hline $\begin{array}{l}\text { Abstraction alteration } \\
\text { Yes } \\
\text { No }\end{array}$ & $\begin{array}{l}12 \\
27\end{array}$ & $\begin{array}{l}30.8 \\
69.2\end{array}$ & $\begin{array}{l}16 \\
46\end{array}$ & $\begin{array}{l}25.8 \\
74.2\end{array}$ & 0.5 \\
\hline $\begin{array}{l}\text { Memory alteration } \\
\text { Yes } \\
\text { No }\end{array}$ & $\begin{array}{l}20 \\
19\end{array}$ & $\begin{array}{l}51.3 \\
48.7\end{array}$ & $\begin{array}{l}30 \\
32\end{array}$ & $\begin{array}{l}47.3 \\
52.7\end{array}$ & 0.7 \\
\hline $\begin{array}{l}\text { Orientation alteration } \\
\text { Yes } \\
\text { No }\end{array}$ & $\begin{array}{l}13 \\
26\end{array}$ & $\begin{array}{l}33.3 \\
66.7\end{array}$ & $\begin{array}{l}16 \\
46\end{array}$ & $\begin{array}{l}25.8 \\
74.2\end{array}$ & 0.4 \\
\hline $\begin{array}{l}\text { Cognitive impairment } \\
\text { Yes } \\
\text { No }\end{array}$ & $\begin{array}{l}20 \\
19\end{array}$ & $\begin{array}{l}51.3 \\
48.7\end{array}$ & $\begin{array}{l}31 \\
34\end{array}$ & $\begin{array}{l}47.7 \\
52.3\end{array}$ & 0.7 \\
\hline $\begin{array}{l}\text { Cognitive sequels } \\
\text { Yes } \\
\text { No }\end{array}$ & $\begin{array}{l}21 \\
15\end{array}$ & $\begin{array}{l}58.3 \\
41.7\end{array}$ & $\begin{array}{l}38 \\
25\end{array}$ & $\begin{array}{l}60.3 \\
39.7\end{array}$ & 0.8 \\
\hline $\begin{array}{l}\text { Severity } \\
\text { Moderate } \\
\text { Severe }\end{array}$ & $\begin{array}{c}11 \\
9\end{array}$ & $\begin{array}{l}55 \\
45\end{array}$ & $\begin{array}{l}13 \\
18\end{array}$ & $\begin{array}{l}41.9 \\
58.1\end{array}$ & 0.3 \\
\hline Overall population & \multicolumn{2}{|c|}{ Cognitive impairment } & \multicolumn{2}{|c|}{ No cognitive impairment } & \\
\hline Sequels at discharge & 36 & 76.6 & 23 & 44.2 & 0.001 \\
\hline
\end{tabular}

Limitations of our research lay in the impossibility to collect missing data in medical records, given that this was a retrospective study; in the absence of longterm follow-up, since continuing with $100 \%$ of the patients was not possible due due to patient deaths and non-attendance at outpatient control visits; as well as in the sample size. In view of the above, for the scope of this investigation to be improved, it should be carried out in a larger population; therefore, a national multi-center study would be really enriching.

\section{Conclusions}

In this retrospective, analytical, cross-sectional study, we report neurocognitive alterations in a Mexican population with central nervous system TB with 
and without HIV coinfection. Clinical, imaging and laboratory manifestations corresponded to those described in national and international investigations carried out over the past decade. ${ }^{18}{ }^{21}$ There were no data consistent with a statistically significant relationship between cognitive impairment and HIV coinfection, probably due to the small sample size. Cognitive impairment decreases patient quality of life. ${ }^{22}$ Cognitive sequelae showed improvement during follow-up with adequate management and patients' therapeutic control; therefore, it is of the utmost importance for diagnosis to be established in a timely manner and to initiate, to the extent possible, an effective treatment and ensure therapeutic adherence in order to prevent complications.

\section{Acknowledgments}

To all personnel at infectology laboratory, with special mention to Dr. José Luis Soto Hernández.

\section{Funding}

The authors declare that they did not receive any funding.

\section{Conflict of interests}

The authors declare that they have no conflicts of interest.

\section{Ethical disclosures}

Protection of human and animal subjects. The authors declare that no experiments were performed on humans or animals for this research.

Confidentiality of data. The authors declare that they followed the protocols of their work center on the publication of patient data.
Right to privacy and informed consent. The authors declare that no patient data appear in this article.

\section{References}

1. World Health Organization [Internet]. Switzerland: Global Tuberculosis Report 2019; 2020.

2. Chinyama J, Ngoma MS, Menon AJ, Hestad K, Heaton RK. The effect of pulmonary tuberculosis on neurocognitive function in HIV infected adult patients in Lusaka, Zambia. Med J Zambia. 2016;43:199-206.

3. Hunter RL. The pathogenesis of tuberculosis: the early infiltrate of post-primary (adult pulmonary) tuberculosis: a distinct disease entity. Front Immunol. 2018;9:2108.

4. Behar SM, Divangahi M, Remold HG. Evasion of innate immunity by Mycobacterium tuberculosis: is death an exits strategy? Nat Rev Microbiol. 2010;8:668-74.

5. Chen HL, Lu CH, Chang CD, Chen PC, Chen MH, Hsu NW, et al. Structural deficits and cognitive impairment in tuberculous meningitis. BMC Infect Dis. 2015;15:279.

6. Gale SD, Erickson LD, Berrett A, Brown BL, Hedges DW. Infectious disease burden and cognitive function in young to middle-aged adults. Brain Behav Immun. 2016:52:161-8.

7. Davis, AG, Nightingale S, Springer PE, Solomons R, Arenivas A, Wilkinson RJ, et al. Neurocognitive and functional impairment in adult and paediatric tuberculous meningitis. Wellcome Open Res. 2019;4:178.

8. Sanford AM. Mild cognitive impairment. Clin Geriatr Med. 2017;33:325-37.

9. Hestad KA, Chinyama J, Anitha MJ, Ngoma MS, McCutchan JA, Franklin $\mathrm{DR}$, et al. Cognitive impairment in Zambians with HIV infection and pulmonary tuberculosis. J Acquir Immune Defic Syndr. 2019;80:110-7.

10. Boletín Epidemiológico. Sistema Nacional de Vigilancia Epidemiológica Sistema Único de Información. Semana Epidemiológica 36. Mexico: Secretaría de Salud; 2019.

11. Marais S, Thwaites G, Schoeman JF, Török ME, Misra UK, Prasad K, et al. Tuberculous meningitis: a uniform case definition for use in clinical research. Lancet Infect Dis. 2010;10:803-12.

12. Defunciones por Tuberculosis Todas Formas 1990-2015. Mexico: Centro Nacional de Programas Preventivos y Control de Enfermedades; 2015.

13. Wilkinson R, Rohlwink U, Misra U, van Crevel R, Dooley KE, Caws M, et al. Tuberculous meningitis. Nat Rev Neurol. 2017;13:581-98.

14. Cadena AM, Fortune SM, Flynn JL. Heterogeneity in tuberculosis. Nat Rev Immunol. 2017;17:691-702.

15. Pehlivanoglu F, Yasar KK, Sengoz G. Tuberculous meningitis in adults: a review of 160 cases. ScientificWorldJournal. 2012;2012:169028.

16. Devlin KN, Giovannetti T. Heterogeneity of neuropsychological impairment in HIV infection: contributions from mild cognitive impairment. Neuropsychol Rev. 2017;27:101-23.

17. Nightingale $S$, Winston $A$. Measuring and managing cognitive impairment in HIV. AIDS. 2017;31:S165-72.

18. Furlow B. Tuberculosis: a review and update. Radiol Technol. 2010;82:33-52.

19. Patkar D, Narang J, Yanamandala R, Lawande M, Shah GV. Central nervous system tuberculosis: pathophysiology and imaging findings. Neuroimaging Clin N Am. 2012;22:677-705.

20. Sáenz B, Hernandez-Pando R, Fragoso G, Bottasso O, Cárdenas G. The dual face of central nervous system tuberculosis: a new Janus Bifrons? Tuberculosis (Edinb). 2013;93:130-5.

21. Schaller MA, Wicke F, Foerch C, Weidauer S. Central nervous system tuberculosis: etiology, clinical manifestations and neuroradiological features. Clin Neuroradiol. 2019;29:3-18.

22. Rubin LH, Maki PM. HIV, depression, and cognitive impairment in the era of effective antiretroviral therapy. Curr HIV/AIDS Rep. 2019;16:82-95. 